\title{
SLC3A2 Gene
}

National Cancer Institute

\section{Source}

National Cancer Institute. SLC3A2 Gene. NCI Thesaurus. Code C124115.

This gene plays a role in promoting the transport of amino acids. 